\title{
SOCIO-ECONOMIC AND CULTURAL CONTEXTS OF THE ADVENT OF PERSONAL STYLES IN IRANIAN POPULAR MUSIC IN 1970'S
}

\author{
Sara Kariman \\ Science \& culture university, Tehran
}

\begin{abstract}
This study was conducted to examine factors affecting the advent of personal styles in popular music with a sociologic approach using opinions of Neo-Marxist thinkers and organizational theory about art generation. In this regard, economic, political, social and cultural contexts of Iran during(1970s) were addressed reviewing historical events of that period and it was concluded that advent of personal styles were outcomes of changes and transformations in approaches within mentioned contexts so that they could effect on relationships between artist, users and art producers directly. At the next step of this study, function of celebrity industry and its relation with economic development and capitalism culture was described and it was found that personal styles in popular music are originated from the mentioned economic policy in art and advent of stars in music world. Also in this article we explain about the quiddity and features of personal style in art and specifically popular music. Three artists (a songwriter, a singer, composer), who had effective activity in Iranian popular music in 1970s, were collected as case study of this research. Characteristics of these artists, both artistically and individually have been adapted with indications of personal style, after attribution of this adjective to these artists by finding effective factors we will analyze how thy emerged and we will analyze the mechanism of the influence of cultural and historical events on personal style's growth and emergence in Iranian popular music then this will be analyzed by sociological theories and will make effort to adapt those theories with Iranian social and artistic circumstances.
\end{abstract}

Keywords: cultural context, Iranian Popular Music

\section{INTRODUCTION}

Popular music is the symbol of community that is developed relatively through labor division with a clear distinguishes between producer and consumer in which, cultural productions are created by professionals, sold in public markets and reproduced by mass media (Fatemi, 2014, P. 118). There is a significant qualitative difference in an industrialized society that is in relation with the concept of industrialization within a process that musical life depends on it; in this case, popular music is belonged to the societies with advanced labour division and obvious distinction between producer and consumer. In such societies, cultural products are extensively produced by professionals and sold in a public markets also broadcasted through mass media (Billy, 2003, P. 8).

Iranian society that was transformed in solar 50s considering its political, economic, social and cultural aspects experienced a different cultural production and consumption. Popular music is the outcome of capitalism world and the most underlying cultural product for consumption of public (Adorno \& Horkheimer, 2005). The mentioned period in Iran was changed under the effect of changes creating in contexts affecting popular music production then continued with some new approaches and aspects such as advent and emphasis on celebrity making, bolding economic and commercial aspects, and paying attention to social-political issues. The advent of personal styles is another innovative phenomenon in popular music at that era in Iran.

Style in music points to a specific method to use melody, rhythm, acoustic version, dynamism, harmony, context and form. Each specific method in using these elements may lead to creation of an acoustic quality that is unique. In addition, in case of speaking about the style of a specific composer or a group of composers, music of a country or style of a certain period, works created in a geographical area or Submit Date: 09.01.2018, Acceptance Date: 23.02.2018, DOI NO: 10.7456/1080MSE/140 
The Turkish Online Journal of Design, Art and Communication - TOJDAC

ISSN: 2146-5193, March 2018 Special Edition, p. 338-347

period have a similar style. However, all of composers that use similar musical notes can create their own personal styles such as people who wear cloths based on a similar style while have their own specific appearance (Kimi Yen, 155).

In addition to mentioned factors, popular music is composed of other effective indicators such as coverage method, performance, etc. that are important in popular music study and analysis (Tagg, 1988). In accordance with importance and emphasis of this kind of music on the lyrics and meaning of songs, the taste and technic of songwriter and composer can effect on production of this kind of music; these actions are usually done by different people in Iran. In 1970s in the popular music field of Iran some artists were appeared who had exclusive personal style. The most significant of these artists are: Farhad Mehrad(singer), Esfandiar Monfared Zadeh( composer) and Iraj Janati Ataei(song writer) that were collected as case study of this research, In th following we will also discuss about the quiddity of personal style and how we predicate the adjective an artist. This study was conducted to analyze effective economic-political-social, and cultural factors that are creators of personal styles in popular music; theoretical approach of this study is sociological search for this phenomenon benefitting from Neo-Marxist ideas and organizational theory for cultural production. This research is a fundamental research type and its methodology is analytical- descriptive. The data are collected by desk research method. The aim of this study is to scrutinize sociopolitical and cultural contexts of the advent of the artists having personal style in Iranian popular music in 1970s.

\section{METHODOLOGY}

This research is a fundamental research type and its methodology is analytical- descriptive. The data are collected by desk research method. The aim of this study is to scrutinize sociopolitical and cultural contexts of the advent of the artists having personal style in Iranian popular music in 1970s.

\section{Sociological Neo-Marxist theories in determining concept of cultural production}

One of the fundamental modern research approaches is Marxist and neo-Marxist theories about relationships existing in cultural contexts. Metamorphosis in relations and requirements of cultural productions and its entrance to economy and commercial market is based on the study of effective conditions in production and cycles that are creators of art and culture. Production is a meaningful term in economy. In economics, "production" is defined as changing natural resources or pre-produced materials mixing them with labor and capital (Edgar \& Sejoik, 2009, P. 198).

The matter of production has been highlighted due to penetration of capitalism in all human aspects such as culture. Marx was the first man who studied "production" in context of culture. In fact, Marx was the first person who attributed the historical concept of production to culture. He challenged traditional aesthetic approaches and separation of art from culture production within social and political contexts. Marx theory is against traditional aesthetic theory that was the base for majority of cultural studies. The object and art work were examined separately regardless of social-political-economic effects. The issue of "non-material production" or "cultural production" was more considered according to the cultural changes and propensities created among persons who criticized determinisms.

Among Neo-Marxists and after "cultural turn" obtained from modern interpretation of Marx's works, followers of critical theory more considered the addressed concept of this issue named "cultural production". In opinion of followers of critical school, the reality of capitalism society was not economy but culture. According to them, domination focus has transferred from economy to culture scope in modern world (Roysters, 2003, P. 202).

Critical theorists created a concept that is deeply related to "cultural production" so that they conduct studies on "culture industry". "Culture industry" in indeed description of a realities and bases of "cultural production" within capitalism era.

"In capitalism world, the culture makes all things similar so that film, radio and journals form a system. Each branch of culture is monotone and all branches also form a monotonic system..." (Adorno \&

Submit Date: 09.01.2018, Acceptance Date: 23.02.2018, DOI NO: 10.7456/1080MSE/140

Research Article - This article was checked by Turnitin

Copyright () The Turkish Online Journal of Design, Art and Communication 
The Turkish Online Journal of Design, Art and Communication - TOJDAC

ISSN: 2146-5193, March 2018 Special Edition, p. 338-347

Horkheimer, 2005, P. 209). Critical school considers culture production as a mass production creating for leisure time of people. These productions get in line with ideology of ruling class satisfying people through usage of cultural production.

In opinion of Adorno and Horkheimer, capitalism has destroyed beauty and aesthetics as the basic factors for mass production. According to their viewpoint, properties of capitalism has eliminated effective factors in cultural production such as ethics, beauty, and technic just considered political objectives choosing factors to achieve political goals without any independency in practice. One of properties of critical school headed by Adorno in case of "cultural production" is the difference between "beautiful issue" and "socio-economic issue" (Born, 2009, P. 52). In general, cultural approach and Adorno assume that cultural production is a matter that should be used by capitalism society and it has no goal except for political effectiveness (Adorno \& Horkheimer, 2005, P. 311).

Besides thinkers mentioned herein, Walter Benjamin, another Neo-Marxist, addressed cultural production and reproduction as a spiritual and non-material issue. Benjamin concentrated more on the conditions required for an art work and introduced his opinions with some presumptions based on critical-Marxist theories so that he studied the effect of technology on mass production and massive art works in an article entitled "work of art in the age of mechanical reproduction" (1969) (Zwmiran, 2008, P. 10). Althusser also did not directly point to the concept of "cultural production" and when speaks about repressive policies considers "cultural production" as a mean to enhance ideology of government through responsible institutes. In his opinion, "cultural production" is ideology production. "The role of repressive policies of government is use of force (physical force or any other type) to actualize political conditions for production that are exploitation relationships in capitalism world" (Althusser, 2008, P. 43).

\section{Organizational sociological theoretical approach to explain the concept of cultural production}

This viewpoint, like Marxist and Neo-Marxist theories, is against the belief that artistic production is a cultural production and its founders are separated from social structure that their only concern is creation of aesthetic works.

This approach is inspired by the mainstream of sociology in 1950s and 1970s in which, cognitivefunctional sociology criticizes the individual perception of cultural production and the idea of "creator artist". According to this viewpoint, the actor is not free to have any action or opinion and creates under the rules and regulations imposed to his by the society. Majority of theories under the title of sociological approach to culture production or organizational sociological approach are affected by opinions and works of Richard Peterson, a sociologist who made a relation between sociological study on culture and sociological studies of organizations (Tanner, 2003, P. 70).

Ian Craib presented a different idea in this field publishing the famous article entitled "cultural production" (1976); he introduced music production as an aspect of culture that is the consequent of organizational and institutional processes that induce aesthetic approach to mass production. In his opinion, innovation and creativity in works of an artist is the only opportunities that their conditions are provided by organizations and institutions. "Production World" or "Art World" is the significant point in this analysis not the actor or producer. "Art World" is composed of all producers, organizations, and institutions that are required to produce cultural products such as music, poem, novel, painting, and photo, etc. (Beacker, 1976, P. 4).

\section{POLITICAL, ECONOMIC AND SOCIAL CONTEXTS}

The period of 1963-1973 is one of periods with relative economic stability in prices, wages, and revenues of government and this was because of adoption of fluctuation-less economic stability program in international economy. The unachieved goal of national oil movement gradually realized at early 1970s. Since 1970 Iranian government dominated on foreign active companies in scope of oil production and pricing due to increase in importance of oil producing countries and position of their international

Submit Date: 09.01.2018, Acceptance Date: 23.02.2018, DOI NO: 10.7456/1080MSE/140

Research Article - This article was checked by Turnitin

Copyright () The Turkish Online Journal of Design, Art and Communication 
The Turkish Online Journal of Design, Art and Communication - TOJDAC

ISSN: 2146-5193, March 2018 Special Edition, p. 338-347

organization (OPEC). In Tehran Conference in 1971, the control of these countries on oil was ended and government obtained 1.4 shares of these countries. A new contract was signed on May 1973 in which, oil industry was under the full control of Iran (Bashiriyeh, P. 131). Oil income was about 555 million dollars in 1963, reached to 958 million dollars, 2.1 billion dollars, and 5 billion dollars in 1968, 1971, and 1974, respectively, and then reached to 20 billion dollars in 1976 when oil prices quadrupled in global markets (Abrahamian, 2014, P. 525).

Some unexpected economic movements occurred three years after price increase. First, fifth economic program that had been initiated one year ago was revised and construction budget increased to 100 billion dollars from the initial budget of 36 billion dollar and this budget was supplied by oil.

Despite the warnings given by economists, Shah decided on correcting this program. Education (elementary and higher education) became free; food subsidies increased and there was $125 \%$ increase in current costs in 1974 and budget increased to $250 \%$ with an unexpected growth rate. Therefore, money supply increased; money volume increased by the rate of 580\% during 1962-1972; unemployment was almost eradicated and reached to $1 \%$ (Bashirieh, 2014, P. 132).

The direct implication of such increase in wealth was investment stimulation and increased supply of products. Worker class also benefitted from this wealth for a short period after increases in oil income. Demands related to increased wages faced some governmental barriers after several strikes during 19711972; first, wages increased by $25 \%$ rate and this increase reached to $100 \%$ in 1973 and to $200 \%$ in 1975 and then increased up to $400 \%$ during 1971-1975. After 1973, increase in wages was higher than increase in consuming products indicators while consuming indicator increased up to $40 \%$ during 19711974 and industrial wages increased up to $90 \%$. Increase in wages caused intensive immigration of villagers so that two years after increased in oil incomes most of the people benefitted from this unexpected wealth (Bashirieh, 2014, Pp. 133-135).

Velocity of immigration of villagers evacuated villages. In 1975, residents of 8000 villages left their villages to live in cities. A big part of these incomes was spent on big cities, particularly Tehran, to establish cultural and entertainment facilities leading to life of luxury and immigration of numerous villagers to Tehran and other mega cities so that this issues led to important cultural and social consequences.

A big part of this huge income was not spent on construction plans but on increasing imports and development of service sector country; in this case, the city was most affected by these transformations (Ahmadian, 2004, P. 151). Urban population of Tehran reached from 30555 to 15854 during 1956-1976 by the growth rate of $4.8 \%$ and a big part of this population growth was the consequence of immigration from villages to cities (Khatam, 2001, P. 75). Population of Tehran consisted 1.5\% of total population of Iran in 1976 and 38\% of people were living in cities in 1966 and 48\% were living in cities in 1976. In case of addressing transformations in urban community during 60s and 70s, several properties can be pointed: first, the concept of fast urbanization was used to describe increasing growth of urban population compared to previous era and this was because of the collapsed agricultural economy and rural life after land reforms and dependency of urbanism to oil income instead of surplus of agricultural production. Second, failure of police officers in urban system and great series phenomenon in capital were emphasized and this was the consequence of the role of Tehran (capital of Iran) as the location in which, national economy met the international economy and there was exclusion of economic surplus of country. Third, inappropriate growth of service sectors compared to increase in industrial and agricultural activities that middle class is the consequence of such growth. Fourth, change in domestic consuming models. Apparently, propagation of consumption models and western culture among middle class is either cause or effect of transformation in consumption patterns and change in production structure of country (Khatam, 2001, P. 79). According to data obtained from consensus during 19561976, the dominant growth of new middle class can be seen in urban population; number of scientifictechnical and specialized jobs, managers, administrative employees and military jobs, which required training courses within a new educational-technical system, reached to 1254000 members from 264000 Submit Date: 09.01.2018, Acceptance Date: 23.02.2018, DOI NO: 10.7456/1080MSE/140

Research Article - This article was checked by Turnitin

Copyright () The Turkish Online Journal of Design, Art and Communication 
The Turkish Online Journal of Design, Art and Communication - TOJDAC

ISSN: 2146-5193, March 2018 Special Edition, p. 338-347

members (about five times) so that the share of urban jobs reached to $30 \%$ of urban employment from $13 \%$ (Khatam, 2001, P. 82).

Moreover, expansion of education led to social movements in urban households. Number of university students quadrupled during 1950-1960 and number of school students reached from lower than 1 million to 3.6 million members during 1956-1968. 1970s was a specific time in expansion of higher education in Iran (Ghaneirad, 2009).

New social classes emerged in 1970s and consisted of 4 following major classes:

1- Upper class: this class consisted of about1000 natives.

2- Prosperous middle class: this class consisted of about 1 million households; first group were about half of million merchants, workshop owners, businessman; second group were shopkeepers and relative wealthy investors that had invested in malls; third group were Imams of the congregation of some mosques.

3- Employee middle class: number of employees doubled after implementation of development plans during 1960s increasing from 310.000 members in 1956 to more than 630.000 members in 1966. This class consisted of employees, teachers, and diplomat workers.

4- Worker class: number of these members increased more than 5 times during 1963-1976 so that most of them were workers of oil industry, power plants, electricity, gas and mining centers with number of about 1.2 million (Ahmadian, 2004, P. 151).

Construction plans has high effect on urban population. Second and third development plans allocated more than 2.5 billion dollars to industry to achieve two important objectives including production of consuming products for domestic market such as cloths, food material, car, etc. and encouraging mother industries such as oil, gas, coal, copper, steel, petrochemical, aluminum, and mechanical tools. Therefore, Iran experienced a small industrial revolution focusing on huge governmental investments during 1963-1976. Share of industrial productions in GNP reached from $11 \%$ to $17 \%$ and annual industrial production increased to $20 \%$ from 5\%. In addition, number of small factories (with 10-49 workers) increased from 1520 to more than 7000 factories, medium-sized factories (with 50-500 workers) increased from 295 to 830 factories, and number of large factories (with more than 500 workers) reached from 105 to 159 factories (Abrahamian, 2014, P. 528).

1.9 billion dollars was anticipated for human resource sector in third and fourth development plans. Therefore, number of hospital beds reached to 48000 from 24.126 beds; number of healthcare clinics increased from 700 to 2800 clinics, number of nurses increased from 1965 to 4105 members and number of practitioners reached from 4500 to 12750 members. In this regard, famines and contagious diseases reduced mortality rate among children, increased number of children and increased 25840000 -member population in 1966 to 33491000 members in 1966; therefore, a half of population of Iran was younger than 16 and tow third of it was below 30 at the middle of 1970s (Abrahamian, 2014, P. 529).

The budgets spent on human resources improved educational status of Iran. Moreover, establishment of 12 new universities, in particular universities named Pahlavi, Shiraz, Ferdowsi of Mashhad, Jondishapoor in Ahvaz, National Universities of Teacher Training and Industrial University of Ariamehr in Tehran, increased number of students from 24885 to 154215 members. Educational system of Iran was enhanced more than three times during these 14 years. Since new schools, healthcare facilities, and industrial factories were centralized in cities, socio-economic development occurred between 1963 and 1977 affected urban population deeply (Abrahamian, 2014, P. 530). These development plans created such shortage in field of trained employees that government had to employ foreign technicians and encouraged women to work in service and public scopes such as education and nursery. Teacher Training University consisted of $86 \%$ of new female students. In this regard, this education system trained a large number of women for mediocre jobs (Abrahamian, 2014, P. 533).

All of the mentioned transformations and advent of middle class, which had a fix and sufficient income, were along with changes in life style and consuming patterns; in addition, advent of new cultural Submit Date: 09.01.2018, Acceptance Date: 23.02.2018, DOI NO: 10.7456/1080MSE/140

Research Article - This article was checked by Turnitin Copyright $\odot$ The Turkish Online Journal of Design, Art and Communication 
The Turkish Online Journal of Design, Art and Communication - TOJDAC

ISSN: 2146-5193, March 2018 Special Edition, p. 338-347

phenomena that were affected by global transformations changed cultural consumption of public marked this era with numerous newly cultural phenomena.

\section{CULTURAL CONTEXTS}

Mass media had a significant growth during these years. Umber of radios reached from 2 million to 4 million; number of TV sets reached from 120.000 to 1.700 .000 sets and number of sold cinema tickets reached from 20 to 110 million tickets (Abrahamian, 2014, P. 533). Statistical population of Supreme Council of Art and Culture in 1976 indicates that 48 million people went to the cinema annually and $76 \%$ of cinema audiences were at age range of 15-30; accordingly, 36.486 .000 young people watched films in cinemas per year (Dorostkar, 1992, P. 72).

In addition, Television as one of the most important tools of culture could effect on formation and transformation of public culture during 1970s. TV initiated its work in Iran in 1958 and managed by private sector and its costs were covered by advertisements. Another transmitter was sent to Abadan in 1961 and an amplifier transmitter was established in Ahvaz. National TV of Iran started working in 1969 and then in 1971 National TV and IRAN TV were merged and programs were broadcasted through 2 channels. Number of programs, TV shows, and series increased significantly during this period so that it can be stated that series started to be produced in Iran at late 1960s; TV shows and music programs were increasingly broadcasted during this period so that TV became a place to introduce and broadcast music freely for public.

As the period of 1951-1971 is named as the radio era in many of references, 1970s can be mentioned as the start point of TV era. TV played a vital role as the most important mass media in creating cultural consumption patterns during these years. On the other hand, TV made it possible for watchers to see modern and western world and event occurring all around the world while it was not possible for Iranian citizens before that to see life, culture and clothing of a western citizen and TV made it possible to see and use another pattern differ from domestic traditional patterns and indigenous heroes. In this regard, cultural behaviors and consumptions became similar to patterns used by western citizens. TV shows were the most popular TV programs that usually related to music so that watchers were waiting to see celebrities in these programs per week. The most popular shows at that era are as follows: Cheshmak (Twinkle), Rangarang (Colorful), Varite Shab (Variety of Night), Zangooleha (Bells), Mikhak Noghrei (Silver Cloves). These popular programs played an undeniable role in production and advertisement of music stars and popularity of new celebrities. Moreover, these programs were a way to show the last fashion designs that was one of attractions of such programs so that many of youths imitated the fashion and make up of presenter and celebrities ${ }^{1}$.

Production and broadcasting of series was another cultural achievement of TV and this emerging phenomenon was another aspect of show that had its own cultural effects. All of the TV effects contributed to similar cultural consumption in middle class and a popular culture among them. 60.1357 series were produced since the beginning of 1970s totally so that this statistics was several times more than it was in 1960s. On the other hand, journals and magazines had a significant role in releasing star news and promoting cultural patterns; some of these popular journals in 1970s can be named as Zane Rooz (Today's Woman), Tamasha (Watch), Javanan Emrooz (Today's Youth), Etelaat Haftegy (Weekly Information), Khandaniha (Readable things), Dokhtaran Pesaran (Girls Boys), etc.

Cinema, as another cultural field, also experienced a different era. Production of films increased during 1970s so that annual productions in 1972 increased by the rate of $1.8 \%$ compared to 1966 reached from 50 to 88 films. In addition, creation of the new flow of Iranian cinema at late 1960s and addressing some social issues that was initiated by producing protesting movies such as Gheisar and Gav (the cow) in 1969 attracted many of audiences that were fed up with Farsi Films. The new wave of cinema coincided with production of the first film soundtrack in Iran and many of composers such as Morteza Hananeh

\footnotetext{
${ }^{1}$ For more information refer to Tamasha Magazine Issue 1-60(1972), (pages related to TV-Radio programs announcement) and websites of http://tv50.blogfa.com/tag updated on 16 March 2012
}

Research Article - This article was checked by Turnitin

Copyright (C) The Turkish Online Journal of Design, Art and Communication 
The Turkish Online Journal of Design, Art and Communication - TOJDAC

ISSN: 2146-5193, March 2018 Special Edition, p. 338-347

and Isfandiar Monfaredzade took it as an opportunity to do a serious task and make fine music. There was not any soundtrack made for films in Iran before that and they just made ballad for films. Gheisar was the first Iranian film that soundtrack was made for it.

Many of singers and artists were introducing to the cinema at that time; hence, cinema had an undeniable effect on music flows during 1970s and such issue influenced the music business. Films with title music became popular and could conduct economic flows, production of music and companies.

Establishment of cultural-artistic institutions at that era is another factor affecting cultural aspect of Iran; one of the most important of these institutions is Roodaki and its salons. According to report of activities done in Roodaki Hall during these 9 years from 1967-1978, 546 different programs in 1199 performances were produced in this Hall. Tehran Opera performed 52 opera and operetta within 301 performances. Ballet Organization of Iran performed 33 ballets during 199 nights. Tehran Symphony Orchestra played 94 symphony works 169 times. Evening Group performed 55 programs and Iranian Programs Institution performed 195 programs during 294 nights. 79 artists and international groups performed 91 various programs in Roodaki Hall within 147 performances and 26 programs such as concerts of art students were performed 34 times. Talar TV shows office was established in winter 1974 and could record and show 4 opera, 3 ballets, two programs of Tehran Symphony Orchestra, 3 Iranian music programs, and 9 Iranian dances during a short period (Arianpoor, 2014, P. 264). In addition, 25 international extra-programs were performed in Roodaki Hall in 1976 that the most important programs were as follows: Stuttgart Chamber Orchestra, New London Folk, Soviet Puppet Theater, British Chamber Orchestra led by Georges Arman, etc. (Arianpoor, 2014, P. 271). Official and governmental centers were established at late 1960s to teach and promote music; the center for maintenance and promotion of Iranian music was established in February to collect and search on original Iranian music works; this organization was affiliated to Radio-TV Organization. Officials created this center to prevent from destruction of this musical heritage. Formation of Music Maintenance and promotion collapsed in 1979 (Arianpoor, 2014, P. 271). National Music Academy was formed in 1971 consisting of 10 art students in composing and musical instrument fields (Nasirifar, 2003, P. 120); in addition, Music Workshop for Adolescences and Children was established in National Radio Television Organization of Iran in May 1969 so that more than 538 art students were educating in 50 different classes in 1977. Parallel to activities of Music Workshop for Adolescences and Children, Institute for the Intellectual Development of Children and Young Adults created some music centers in libraries. There were 24 music classes in Tehran and 40 music classes in other cities with educational activities in 1978 (Arianpoor, 2014, P. 221).

Radio and TV were merged in 1971. Many of old artists of Radio were retired or resigned and new persons were replaced and this affected the process of productions and selection of programs and their approaches. Some festivals were hold during those years including Celebration of Art and Culture, Celebration of Shiraz Art, and Toos Celebration to present music productions and make competition between art groups that contributed to international cultural and artistic relationships. These festivals were holding for a decade and this had significant artistic effects. The first Celebration of Art and Culture was hold in 1969 to make international relationships; this festival consisted of music, exhibition of costumes, local dances, songs, etc. Next series of this festival made all of country participated in it so that statistics published at $8^{\text {th }}$ Celebration of Art and Culture reported 2502 programs that had been performed in November 1975 across the country. In total, 10 festivals had been hold until 1977 (Arianpoor, 2014, P. 298). The first Celebration of Shiraz Art was hold in Takht Jamshid (Persepolis) in 1967. In this festival, eastern and western music, theater, film, poetry, paintings, and handicrafts were exhibited and this festival was hold 11 times until 1977 (Arianpoor, 2014, P. 303). The first Toos Celebration was hold in Mashhad in 1975; this festival was hold to celebrate greatness of Ferdowsi and to introduce his national epic, Shahnameh. Dramatic wrestling battles were along with some musical instruments such as Dotar, Sorna (hornpipe) and Dohol (drums) and consisted of some actions including reading Shahnameh and narrative, cinema, show, and music (Arianpoor, 2014, P. 345).

The first Jonas Music Art Program of Iran was opened in Rashid Al-din Fazlollah Hall in Abadan University of Tabriz in 1972; Isfahan was the third city in which, Jonas Music Program was performed.

Research Article - This article was checked by Turnitin

Copyright () The Turkish Online Journal of Design, Art and Communication 
The Turkish Online Journal of Design, Art and Communication - TOJDAC

ISSN: 2146-5193, March 2018 Special Edition, p. 338-347

This organization hold 56 art programs including classic music, light music, Iranian original music, Folkloric dance, ballet and theater during one year. In addition to mentioned cities, Jonas musical of Iran gradually opened in Karaj, Kermanshah, Sanandaj, Abadan, Ahvaz, Sari, Gorgan, Arak, Arianshahr, and Roodbar; Jonas Musical Program sent some art groups to Europe besides artistic activities in Iran's cities (Arianpoor, 2014, P. 342).

Effect of cultural interactions with west and familiarity with western music that had been initiated since years ago establishing "National Music Academy" and "Music High School" led to formation of orchestras and musical associations during $1960 \mathrm{~s}^{1}$.

The first issue of Iran's Music Journal was published in May 1961 headed by Bahman Hirbod and Alimohammad Rashidi and published music articles. At this year, Farabi Orchestra formed headed by Morteza Hannaneh and performed harmonic Iranian music; Women Orchestra also was formed headed by Mostafa Portorab. Moreover, a number of Italian singers were invited by Fine Art Organization of Iran to perform opera on TV for 2 years. At this year, choir group of Iranian Fine Art joined the Tehran Opera (Rahgani, 1998, P. 565).

"Ministry of Art and Culture" was established in December 1964 and Department of Art Education took the responsibility of tasks of former Culture and Fine Art Ministry that was one of sections of Ministry of Culture (Rahgani, 1998, P. 566). Establishment of Pahlavi Institution also had numerous effects on artistic cultural space of society; book publishing was one of activities of Pahlavi Institution. The objective of this institution was development of Persian languages as well as culture and art of Iran. In this regard, the Institution for Book Publish and Translation was established in 1954 so that written and translated works of authors and writers were published in $\operatorname{Iran}^{2}$.

"Music group of Fine Art Faculty of Tehran University" initiated its activity in 1965; four courses of composing, Iranian music, musicology, and music teaching were taught in this university (Rahgani, 1998, P. 566).

Radio and TV were merged under the title of "National Radio-TV of Iran" in 1971. "The Great Orchestra of National Radio-TV of Iran" was established in 1972 headed by Fereidoon Naseri merging all radio orchestras and continued its activity until May 1969. "Tehran Opera Orchestra" headed by Loris Chaknavarian separated from Tehran Symphonic Orchestra in 1972 and City Theater was opened at this year (Rahgani, 1998, P. 567).

The mentioned factors and measures besides informal places such as hotels, clubs, cafes, etc. that were locations for public music performance affected creation of music flows and changed in economic approaches in music production. Art production increased and nature of cultural product was changed for a broad range of community members due to transformations occurred at that decade so that many of such public entertainment places that were cultural and artistic places were emerged. Moreover, programs could be performed by music artists and they could make money in this way.

\section{DISCUSSION AND CONCLUSION}

The outcome of economic, cultural, and social transformations in Iran during 1970s is the advent of personal styles in popular music. Cultural production entered to a new stage at that era because of economic boom, establishment of institutions that supported art, importance of commercial and economic aspects of art, in particular popular music. Advent if celebrity industry is the most important phenomenon that happened during transformations in culture production and its conversion to culture industry; the phenomenon of celebrities world consists of all things that are known about stars by people

\footnotetext{
${ }^{1}$ For more information refer to Rahgani (1998) History of Iran's Music

2 Pahlavi Institute was a non-beneficiary organization managed by board of trustees and received 40 million dollars charity. For more information, refer to preface of Pahlavi Institution in Islamic World Book written by Manijeh Rabiee.
}

Submit Date: 09.01.2018, Acceptance Date: 23.02.2018, DOI NO: 10.7456/1080MSE/140

Research Article - This article was checked by Turnitin

Copyright (C) The Turkish Online Journal of Design, Art and Communication 
The Turkish Online Journal of Design, Art and Communication - TOJDAC

ISSN: 2146-5193, March 2018 Special Edition, p. 338-347

so that image of stars are always multimedia, inter-textual, and huge. Stars are products of media industry (Dayer, 2003, P. 260). Celebrities are involved in this industry; they are not only labor force but also are products so that labor force produces itself as a product. In this case, the star, makeup artist, hair designer, dress designer, and food expert play a vital role (Dayer, 2003, P. 263).

Personal styles indicate the higher position of stars in popular music. Personal styles that are outcomes of individualization of all appearance and physical properties of artist and unique pragmatics of music methods can strengthen emergence and brilliance of the stars in music world and this significant point will not occur except under the effect of social and cultural infrastructures.

As it was mentioned, the concept of "production" of Neo-Marxist ideas entered into the culture. Thinkers of critical school did not consider traditional values of aesthetics and treated cultural production as the outcome of systematic economic relations that are based on high benefit. Hence, the concept of culture industry was applied by these thinkers. Culture industry is used as a tool to dominate over the modern world. Culture production is a mass production that does not follows aesthetics rules so that a beautiful matter differs from a socio-economic matter. They also consider culture production as production of ideology, exploitation and oppression. However, organizational sociology criticizes individualism and personal creativity of artist. This theory introduces innovations created in music world as the outcomes of fields and opportunities considered by organizations and institutions.

According to sociological study of this phenomenon in Iran during 1970s based on Neo-Marxist and organizational approaches, it can be concluded that economic transformations led to advent of middle class and immigration of villagers to cities and a society with capitalized economic relations in which, cultural production follow industrialization rules of culture that are used as tools to dominant the world regarding cultural publicity. Moreover, analysis of this phenomenon with organizational approach indicates that personal styles in popular music of 1970s in Iran are outcomes of structures that led to advent of an artist as supporter and leading organizations. Socio-economic and cultural transformations in Iran led to occurrence of this phenomenon.

\section{REFERENCES}

Ahmadian, Reza. "The impact of Iran's socio-economic transformations on the formation of the urban planning system of Iran", Journal of Political Economy. Issues 209 and 210(2004):140-163. Print.

Becker, Howards." Art world as social type" .I.R Peterson (ed), The production of culture, Beverly Hills. (CA) (1976): pp.41-56.print.

Billy, Jaun." Cultural perspectives in popular people's music: Afghanistan Case." Natalie Chubin's Trans. Mahoor Journal. Issue 22 (2003):224- .print.

Born, Jujino." Against negation in defense of the policy of cultural production: Adorno, aesthetics and social affairs". Beautiful Cognition Journal. Issue 21(2009):49-72.print.

Dorostkar, Reza. 50th anniversary of bankruptcy in all aspects of cinema, Culture and Culture Literature, Issue 390(1992):Pp. 102-105.print.

Dyer, Richard. "Heavenly bodies: stars of cinema and society." Malek Mohammadnia Trans, Arghanoon Pub. Issue 23 (2003):Pp.253-276.Print.

Ghanei rad, Mohammad Amin. Ontological insecurity of urban life in the works of literary intellectualsTehran city in the 1960s, Tehran, Social Studies Journal of Iran, Issue 6(2009):Pp. 72-103.print.

Mohebbi,Seyed Fatemeh. "Surrogate footprint in the media. “Women's Strategic Studies Journal, Issue 8. (2000):Pp. 110-127.print.

Tagg, Philip." Analyzing popular Music, Theory, Method and practice. "popular Music Issue 2(1982):pp.37-65.print.

Zaymran, Mohammad. "Walter Benjamin and the reversals of metaphysical sanctity in art. "Journal of the Academy of Arts, Issue 11 (2008):Pp. 7-18.print.

Adorno,Teodor, Horkheimer,Max. Dialectic and enlightenment: philosophical pieces. Morad Farhadpour and Amir Mehregan Trans, Tehran: New Step Pub, 2005.print.

Research Article - This article was checked by Turnitin

Copyright () The Turkish Online Journal of Design, Art and Communication 
The Turkish Online Journal of Design, Art and Communication - TOJDAC

ISSN: 2146-5193, March 2018 Special Edition, p. 338-347

Althusser, Louis. Ideology and ideological mechanisms of government. Roozbeh Sadr Ara Trans, Tehran: Cheshmeh Pub, 2008.print.

Althusser, Louis. Ideology and ideological mechanisms of government. Roozbeh Sadr Ara Trans, Tehran: Cheshmeh Pub, 2008.print.

Arianpour, Amir Ashraf. Iranian music from the Constitutional Revolution to the Islamic Revolution of Iran.Tehran: Art Academy, 2014.print.

Abrahamian, Yerevan. Iran between two revolutions. Tehran: Ney Pub, 2014.print.

Edgar, Andrew, Sedgwick, Peter. Key concepts in cultural theory. Naseroddin Ali Taghavian Trans, Tehran: Office of Social Planning and Cultural Studies and Research Institute for Cultural and Social Studies, 2009.print.

Bashirieh, Hossein. The social context of the revolution of Iran, Ali Ardestani Trans, Tehran: Contemporary View Pub, 2014.print.

Rahgani, Shour angiz. Iranian music history, Tehran: Pishro Pub, 1998.print.

Royterz, George. Theory of sociology in the contemporary period, Mohsen Solati Trans, Tehran: Scientific Pub.2003.print.

Fatemi, Sasan. The emergence of popular music in Iran. Tehran: Mahoor Pub.2014.print.

Kim Yen, Racher. Understanding and receiving music, Hossein Yasini Trans. Tehran: Cheshmeh Pub, 2008.print.

Mirsepasi, Ali. Review in Iranian modernity. Tehran: New Design Pub, 1998.print.

Nasirifar,Habibollah. The story of Iranian music schools. Tehran: Saless Pub, 2003.print.

Tanner, Jeremy.The sociology of Art, A reader. London: Rutledge, 2003.print.

Rabiee, Manijeh." Pahlavi Institution"/Islamic World Book Issue 4(2015):Pp. 475, http://rch.ac.ir/article/Details/11746

websites of http://tv50.blogfa.com/tag updated on 16 March 2012 